\title{
Copepod composition, abundance and diversity in Makupa Creek, Mombasa, Kenya
}

\author{
M.K.W. Osore ${ }^{1,2}$, F. Fiers ${ }^{2}$ and M.H. Daro 3 \\ ${ }^{1}$ Kenya Marine and Fisheries Research Institute, P. O. Box 81651, Mombasa, Kenya; \\ ${ }^{2}$ Royal Belgian Institute of Natural Sciences, Vautierstraat 29, 1000 Brussels, Belgium; \\ ${ }^{3}$ Free University of Brussels, Pleinlaan 2, 1050 Brussels, Belgium
}

\begin{abstract}
Key words: copepods, marine pollution, mangroves, Makupa creek, Mombasa Harbour, monsoons
Abstract-The taxonomic composition, abundance and spatio-temporal distribution of copepods were analysed from monthly zooplankton samples collected in Makupa creek and Mombasa Harbour (Makupa creek was until recently subjected to considerable dumping of domestic and industrial waste). At least 51 copepod species belonging to 38 genera in the families Calanoida (25), Harpacticoida (5), Poecilostomatoida (7) and Cyclopoida (1) were identified. The most common genera were Acartia, Acrocalanus, Corycaeus, Oncaea and Oithona. Copepods bloomed in the wet months of November and April ( 75 to $\left.158 / \mathrm{m}^{3}\right)$. Abundance was consistently high near the creek mouth and low within the creek enclosure. Copepod diversity $\left(H^{\prime}\right)$ was slightly higher (2.00 to 2.57) during September, November, December, January, May and June and lower (1.30 to 1.95$)$ in the remaining months. Evenness $(J)$ was, however, relatively constant (0.67 to 0.84$)$ during the entire sampling period. These results point to suppressed copepod diversity and abundance in Makupa Creek, and possible reasons for this, which may include environmental degradation caused by pollution, are presented.
\end{abstract}

\section{INTRODUCTION}

Ongoing and recently completed marine research in Kenya and on the East African coast has produced much data and information on zooplankton (e.g. Kimaro \& Jaccarini, 1989; Okemwa, 1989; Osore et al., 1993; Osore et al., 1995; Kitheka et al., 1997; Mwaluma, 2000). However, information on the ecology of copepods is still scanty, and yet this taxonomic group usually comprises the major component of zooplankton in terms of abundance and diversity. Apart from preliminary observations of copepods and their role in the secondary productivity of Tudor creek (Okemwa \& Revis, 1986, 1988; Revis, 1988; Okemwa, 1990, 1992), Gazi Bay (Borger, 1990) and of the upwelling waters of Somalia (Smith \& Lane, 1981), very little is known about the copepods of the East African coast. The existing zooplankton literature of the region only considers copepods as a component of the plankton (Okera, 1974; Reay \& Kimaro, 1984; Osore, 1992, 1994; Osore et al., 1997), and no detailed studies on the group are available.

Table 1 summarises the physical and chemical features documented for Makupa creek compiled from previous studies. The small size of the creek and its location-sandwiched between a busy harbour, a dumpsite and an electric powergenerating plant-are major factors contributing to its pollution. Previous studies in the creek revealed almost complete loss of mangrove vegetation and reduced populations of fish and edible crustaceans (Munga et al., 1994; Williams et al., 1996). Kamau (2001), Mwashote (unpublished data) and Osore et al. (unpublished 
Table 1. Major physical and chemical features of Makupa creek, Mombasa, Kenya, compiled from Kamau (2001), Mwashote (Unpublished data) and Osore et al. (Unpublished data)

\begin{tabular}{|c|c|}
\hline Location: & $\begin{array}{l}\text { Northwest of Mombasa Island } \\
\left(4^{\circ} 02^{\prime} \mathrm{S}, 39^{\circ} 38^{\prime} \mathrm{E}\right)\end{array}$ \\
\hline Surface area $\left(\mathrm{km}^{2)}\right.$ : & $1(0.85$ to 1.1$)$ \\
\hline Depth (m): & $3(0.7-13)$ \\
\hline Water temperature $\left({ }^{\circ} \mathrm{C}\right)$ : & $24.85 \pm 0.50-31.70 \pm 1.50$ \\
\hline Salinity $(\% o)$ : & $29.90 \pm 3.15-35.80 \pm 0.45$ \\
\hline Secchi transparency $(\mathrm{m})$ : & $0.30-1.40$ \\
\hline DO concentration $(\mathrm{mg} / \mathrm{l})$ : & $3.60 \pm 0.90-5.90 \pm 4.40$ \\
\hline $\begin{array}{l}\text { Heavy metal } \\
\text { concentration }(\mu \mathrm{g} / \mathrm{g}) \text { : }\end{array}$ & $\begin{array}{l}\text { In sediments: } \mathrm{Cu}(56-114) \\
\mathrm{Cd}(1-13), \mathrm{Zn}(223-1429), \\
\mathrm{Fe}(\text { up to } 27,718), \mathrm{Pb} \text { (up to 58) } \\
\text { In water: } \mathrm{Cd}(\mathrm{nd}), \mathrm{Pb}(12) \\
\text { In fish: } \mathrm{Cd}(3.9), \mathrm{Pb}(59)\end{array}$ \\
\hline $\begin{array}{l}\text { Chlorophyll- } a \\
\text { concentration }(\mu \mathrm{g} / \mathrm{l}) \text { : }\end{array}$ & $2.05 \pm 0.60-8.00 \pm 6.80$ \\
\hline Monthly rainfall (mm): & $1.9-279$ \\
\hline
\end{tabular}

DO, dissolved oxygen; nd, not detected.

data) have recently reported on aspects of heavy metal concentrations, trends of physico-chemical conditions and the general zooplankton community of Makupa creek. They concluded that although there is contamination by heavy metals in the sediments, water and some commercial fish species, it has not yet reached critical levels.

It is evident that frequent oil spillages from Mombasa Harbour into the creek have reduced the water quality and resulted in the degradation of mangroves and other habitats. The resultant poor water quality may also be detrimental to the recruitment of fish and invertebrates.

The study reported here was conducted as part of collaborative multi-institutional research by the Kenya Marine and Fisheries Research Institute (KMFRI), the Kenya Wildlife Service (KWS) and the Government Chemist Department (GCD). The overall research objective was to assess the causes and status of environmental degradation of Makupa creek. Sampling and analysis of zooplankton were fundamental to this research, as these organisms form the basis of the food chain in the aquatic ecosystem. Results of the general zooplankton survey and also a detailed description of the study area have been submitted elsewhere (Osore et al., unpublished data).

Results of the composition, abundance and distribution of copepods and their seasonal trends at four sampling locations in Makupa creek (Stns $1,2,3,4)$ are described, and compared with a control site in Mombasa Harbour (Stn 5).

\section{MATERIALS AND METHODS}

Makupa creek connects to the Indian Ocean via Mombasa Harbour in Port Reitz creek (Fig. 1). Four sampling sites (Stn 1 to 4) were located in Makupa creek and one (Stn 5) within Mombasa Harbour. Monthly sampling of zooplankton was conducted during daytime high tide from July 1996 to June 1997. A quantitative Bongo net of mesh size $335 \mu \mathrm{m}$ and mouth diameter of $45 \mathrm{~cm}$ equipped with a flowmeter, was used. The net was towed obliquely in subsurface water by a motorboat for 5 minutes and the samples were preserved in 5\% formalin. Subsurface water temperature and salinity were registered using a probe (Aanderaa Display unit 3315 connected to $\mathrm{S} / \mathrm{T}$ sensor 3210 ). Dissolved oxygen was determined in the laboratory by the modified Winkler method (Parsons et al., 1984). Chlorophyll- $a$ concentration was quantified spectrophotometrically by the method described by Parsons et al. (1984). Rainfall data were obtained from the Meteorological Department, Mombasa, Kenya.

For laboratory analysis, the entire zooplankton sample was first screened under a binocular microscope to identify all the taxa present and then one-tenth of each sample was observed in detail (Osore et al., 1997). Identification keys and references were obtained from Giesbrecht (1892), Rose (1933), Owre \& Foyo (1967), Wickstead (1965) and Bradford (1972). Copepods were separated from the rest of the zooplankton and abundance calculated as number of individual copepods per cubic metre (ind. $/ \mathrm{m}^{3}$ ). The ShannonWiener index and Pielou index were used to calculate copepod diversity $\left(H^{\prime}\right)$ and homogeneity $(J)$ respectively (Magurran, 1996). 


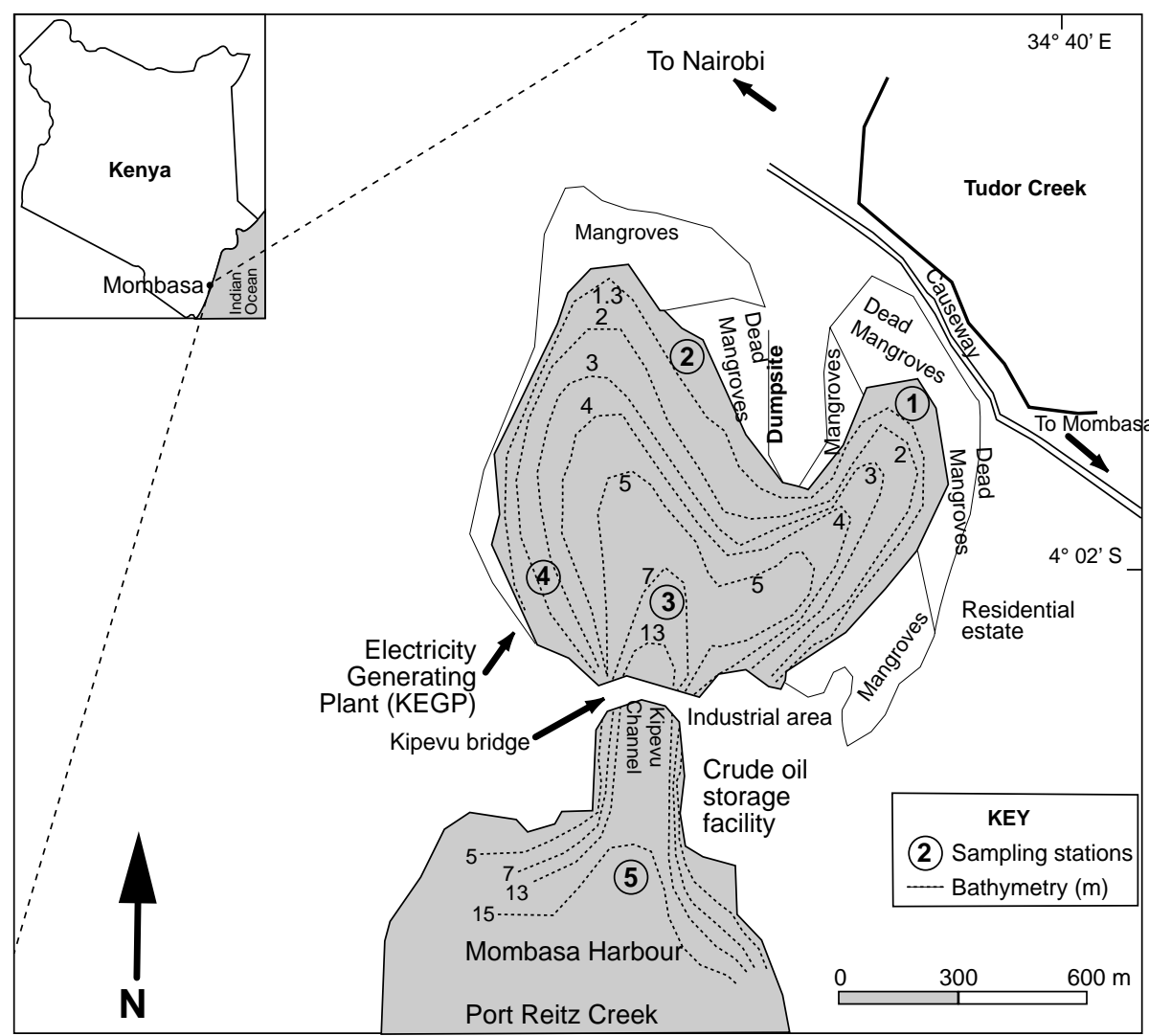

Fig. 1. Map of the study area showing sampling locations in Makupa creek (Stns 1-4) and Mombasa Harbour (Stn 5)

\section{RESULTS AND DISCUSSION}

\section{Environmental variables}

Monthly changes in average environmental variables are shown in Fig. 2a-e. Average dissolved oxygen usually ranged between 3.70 and $5.31 \mathrm{mg} / \mathrm{l}$ and increased to $10.55 \mathrm{mg} / \mathrm{l}$ in November. Chlorophyll- $a$ concentration varied from 2.10 to $8.04 \mu \mathrm{g} / \mathrm{l}$. These high Chlorophyll- $a$ values suggest that the creek has high phytoplankton biomass due to high level of eutrophication. Surface water temperature was highest $\left(31.0^{\circ} \mathrm{C}\right)$ in March and was relatively low $\left(24.9-27.4{ }^{\circ} \mathrm{C}\right)$ from April to August. There was little variation in salinity (35.0-36.0\%o) except in August (29.9\%o) and April (30.7\%o), when it was low. Rainfall was high in April (268 mm), May (279 mm) and November $(136 \mathrm{~mm})$ during the southeast monsoon (SEM) period, but minimal or absent from December to March, the northeast monsoon (NEM) period.

\section{Copepod abundance}

Monthly variations in copepod abundance at the five sampling stations are shown in Fig. 3. Within the creek enclosure (Stns 1-4) abundance ranged from 3 to $88 / \mathrm{m}^{3}$ (Stn 4), 23 to $78 / \mathrm{m}^{3}$ (Stn 3), 2 to $60 / \mathrm{m}^{3}$ (Stn 2) and 1 to $25 / \mathrm{m}^{3}$ (Stn 1); but there was a major peak at this $\mathrm{stn}$ in April $\left(638 / \mathrm{m}^{3}\right)$. The bloom of Pseudodiaptomus sp. caused the prominent peak at Stn 1 in April. Several species of this genus are documented to thrive in brackish water and often form aggregations and swarms (Walter, 1989; Mauchline, 1998). Within Mombasa Harbour (Stn 5), abundance varied between 10 and $209 / \mathrm{m}^{3}$. Peak abundance $\left(209 / \mathrm{m}^{3}\right)$ was observed in December.

Total copepod abundance for all stations was high during the NEM period, which occurred in November to March. The mean value of copepod abundance was also significantly high $(\mathrm{P}=0.001)$ for the NEM compared to SEM period. 


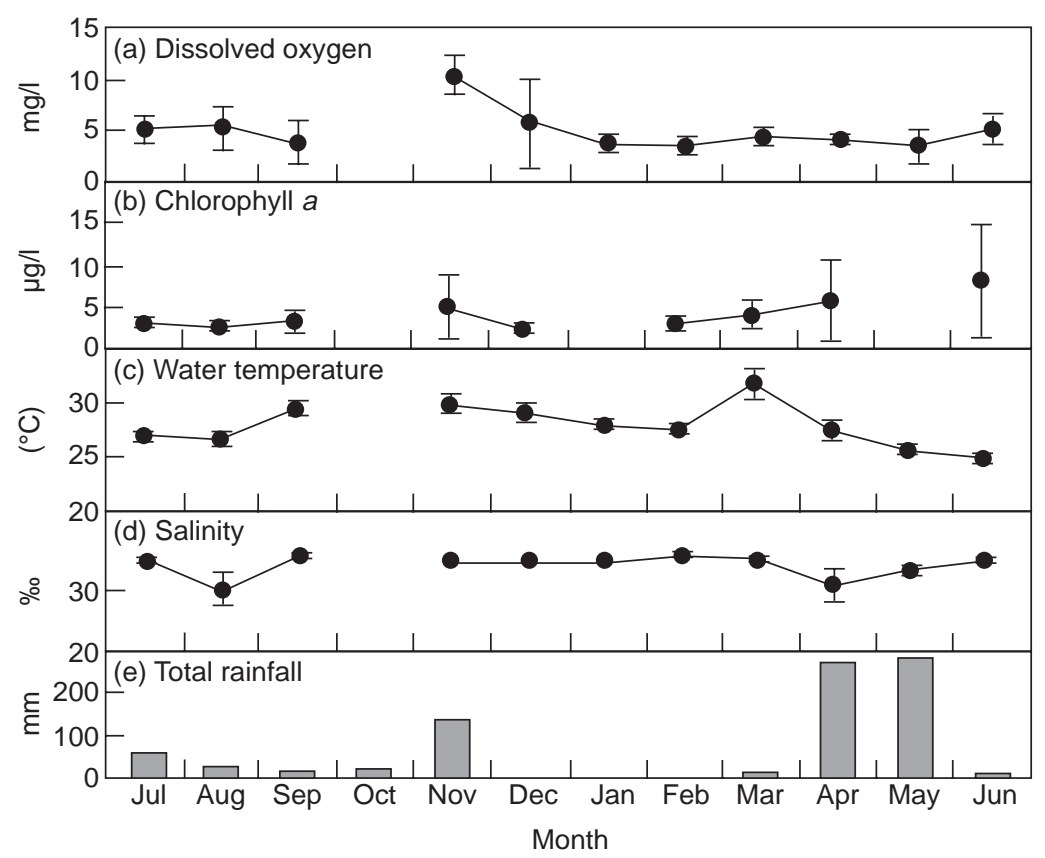

Fig. 2. Environmental variables recorded in the study area. Error bars (in a-d) represent standard deviation. Field sampling was not conducted in October; Chlorophyll- $a$ was not sampled in January and May

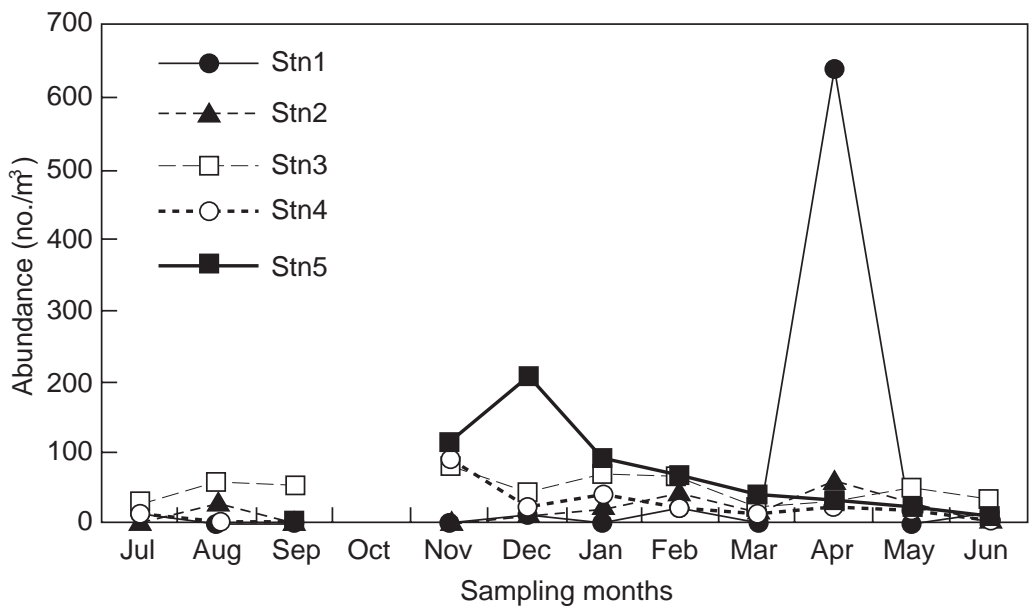

Fig. 3. Monthly abundance $\left(\mathrm{no} / \mathrm{m}^{3}\right)$ of all the copepods counted from each sampling station in the study area from July 1996 to June 1997

Overall, copepod abundance peaked during the NEM period. Similar, high densities of copepods have been reported in the Mombasa Harbour during the NEM (Okemwa, 1992). In the present study, the highest monthly abundance $\left(23\right.$ to $\left.78 / \mathrm{m}^{3}\right)$ was recorded at Stn 3 located at the mouth of the creek and at Stn 5 (10 to $\left.209 / \mathrm{m}^{3}\right)$, which is inside Mombasa Harbour and closer to the open ocean.

\section{Species distribution}

More than 51 taxa from 5 orders, 15 families and 38 genera were identified in this study. Table 2 lists the copepods identified and their mean densities averaged for all the months. Numerically, the most common orders were Calanoida, Poecilostomatoida and Cyclopoida. The Calanoida were mainly 
Table 2. List of copepods identified in Makupa creek and Mombasa Harbour and their densities of occurrence $\left(n o . / \mathrm{m}^{3}\right)$, means for all the months of the study. The most common copepod species are shown in bold typeface and * indicates the most abundant copepod species

\begin{tabular}{|c|c|c|c|c|c|}
\hline Species & Stn1 & $\operatorname{Stn} 2$ & $\operatorname{Stn} 3$ & Stn4 & Stn5 \\
\hline \multicolumn{6}{|l|}{ CALANOIDA } \\
\hline Nannocalanus minor (Claus 1863) & 0 & 0 & 0 & 0 & 1 \\
\hline Canthocalanus pauper Giesbrecht 1888 & 0 & 0 & 3 & 2 & 3 \\
\hline Cosmocalanus sp. & 0 & 0 & 0 & 1 & 0 \\
\hline Undinula vulgaris (Dana 1849)* & 0 & 2 & 7 & 3 & 24 \\
\hline Eucalanus attenuatus (Dana 1849) & 0 & 1 & 1 & 1 & 1 \\
\hline Eucalanus crassus Giesbrecht 1888 & 0 & 0 & 1 & 1 & 1 \\
\hline Eucalanus mисronatus Giesbrecht 1888 & 0 & 1 & 0 & 0 & 1 \\
\hline Eucalanus spp. & 1 & 0 & 5 & 4 & 4 \\
\hline Mecynocera sp. & 0 & 0 & 0 & 0 & 1 \\
\hline Clausocalanus sp.* & 1 & 1 & 6 & 2 & 15 \\
\hline Acrocalanus sp.* & 3 & 12 & 22 & 30 & 49 \\
\hline Calocalanus sp. & 0 & 0 & 0 & 1 & 2 \\
\hline Paracalanus sp. & 0 & 1 & 0 & 1 & 2 \\
\hline Aetideus sp. & 0 & 0 & 2 & 0 & 0 \\
\hline Euchaeta sp. & 0 & 0 & 1 & 0 & 0 \\
\hline Scolecithrix sp. & 0 & 0 & 2 & 0 & 1 \\
\hline Temora discaudata Giesbrecht 1889 & 1 & 0 & 0 & 0 & 1 \\
\hline Temora turbinata (Dana 1849)* & 1 & 5 & 5 & 4 & 8 \\
\hline Centropages furcatus (Dana 1849)* & 0 & 1 & 1 & 1 & 2 \\
\hline Centropages orsini Giesbrecht 1849 & 1 & 1 & 9 & 3 & 68 \\
\hline Candacia spp. & 0 & 0 & 1 & 1 & 1 \\
\hline Calanopia elliptica (Dana 1849) & 0 & 0 & 0 & 1 & 1 \\
\hline Calanopia thompsoni A. Scott 1909 & 3 & 1 & 0 & 1 & 0 \\
\hline Calanopia minor A. Scott 1902 & 0 & 0 & 1 & 0 & 0 \\
\hline Labidocera acuta (Dana 1849) & 0 & 1 & 3 & 0 & 1 \\
\hline Labidocera minuta Giesbrecht 1889 & 0 & 0 & 0 & 0 & 1 \\
\hline Labidocera pavo Giesbrecht 1889 & 0 & 0 & 1 & 1 & 1 \\
\hline Labidocera orsini Giesbrecht 1889 & 0 & 1 & 3 & 5 & 1 \\
\hline Labidocera bipinata Tanaka 1936 & 0 & 1 & 0 & 0 & 10 \\
\hline Labidocera spp. & 1 & 6 & 2 & 1 & 1 \\
\hline Pseudodiaptomus sp.* & 629 & 30 & 3 & 5 & 0 \\
\hline Pontella spp. & 0 & 1 & 1 & 1 & 1 \\
\hline Pontellina plumata (Dana 1849) & 0 & 1 & 0 & 1 & 5 \\
\hline Pontellopsis spp. & 0 & 1 & 2 & 1 & 0 \\
\hline Tortanus spp.* & 4 & 24 & 9 & 3 & 15 \\
\hline Acartia spp.* & 6 & 15 & 13 & 9 & 25 \\
\hline \multicolumn{6}{|l|}{ CYCLOPOIDA } \\
\hline Oithona spp.* & 10 & 10 & 31 & 26 & 20 \\
\hline \multicolumn{6}{|l|}{ POECILOSTOMATOIDA } \\
\hline Oncaea spp.* & 1 & 2 & 10 & 3 & 12 \\
\hline Pachos punctatum (Claus 1863) & 0 & 0 & 0 & 0 & 1 \\
\hline Corycaeus spp.* & 2 & 8 & 32 & 12 & 25 \\
\hline Copilia sp. & 0 & 0 & 4 & 0 & 0 \\
\hline Saphirella sp. & 3 & 1 & 0 & 1 & 0 \\
\hline Saphirina sp. & 1 & 0 & 2 & 0 & 1 \\
\hline Peltidium sp. & 0 & 1 & 1 & 0 & 1 \\
\hline \multicolumn{6}{|l|}{ HARPACTICOIDA } \\
\hline Microsetella sp. & 1 & 0 & 1 & 1 & 1 \\
\hline Macrosetella sp. & 0 & 0 & 1 & 1 & 1 \\
\hline Clytemnestra sp. & 1 & 1 & 0 & 0 & 1 \\
\hline Aegisthus spp. & 1 & 0 & 0 & 0 & 0 \\
\hline Other Harpacticoida & 1 & 1 & 1 & 3 & 1 \\
\hline MONSTRILLOIDA & 0 & 1 & 0 & 1 & 1 \\
\hline Copepoda nauplii & 1 & 1 & 1 & 1 & 1 \\
\hline Total no. of species & 21 & 29 & 34 & 34 & 40 \\
\hline
\end{tabular}


represented by the genera Acrocalanus, Acartia, Centropages, Temora and Tortanus. Pseudodiaptomus only bloomed occasionally at Stn 1 . The Poecilostomatioda were mainly represented by the genera Corycaeus and Oncaea while the Cyclopoida were represented by members of the genus Oithona.

Okemwa \& Revis (1986) encountered nearly the same number of copepod species (52) in Tudor creek, but recorded more families (24) and fewer genera (30) compared to the present study. Time series of $24 \mathrm{hr}$ surveys within Mombasa Harbour, located in the immediate neighbourhood of Makupa creek, yielded 100 species belonging to 29 families and 37 genera (Okemwa, 1992). This survey utilised smaller $(180 \mu \mathrm{m})$ mesh size nets than ours $(350 \mu \mathrm{m})$, and therefore captured a wider spectrum of copepods, especially Poecilostomatoida and Cyclopoida. Net filtration efficiency was also higher in both Tudor creek and Mombasa Harbour (most probably due to less clogging) since the water was less muddy and had less particulate matter as indicated by its low turbidity.

Our study identified 21 copepod species at Stn 1, 29 at Stn 2, 34 at both Stns 3 and 4 and 40 at Stn 5 . The most abundant copepods in this study were Undinula vulgaris (Dana 1849), Clausocalanus sp., Acrocalanus sp., Temora turbinata (Dana 1849), Centropages orsini Giesbrecht 1889, Pseudodiaptomus sp., Tortanus spp., Acartia spp., Oithona spp., Oncaea spp. and Corycaeus spp. (Table 2). Their combined abundance constituted 43-90\% of the entire copepod population. Labidocera (> 6), Eucalanus (> 4) and Calanopia (>3) comprised the most species.

\section{Characteristic copepod genera of the study area}

The five most common copepod genera in the study area were Acartia, Corycaeus, Oncaea, Acrocalanus and Oithona. These five main copepod taxa constituted an average abundance of $72 \%$ (range 45-90\%) of the total number of copepods encountered. Table 2 shows that these genera occurred in all the sampling stations at maximum monthly abundance of 6-25/m $3 \mathrm{~m}^{3}$ (Acartia spp.), 2$32 / \mathrm{m}^{3}$ (Corycaeus spp.), 1-12/m $\mathrm{m}^{3}$ (Oncaea spp.), $3-49 / \mathrm{m}^{3}$ (Acrocalanus sp.) and $10-31 / \mathrm{m}^{3}$ (Oithona spp.). Sampling was not conducted in October at any of the Stns, in January at Stn 1, in July at Stns 4 and 5; nor in August at Stn 5.

\section{Copepod diversity and homogeneity}

Shannon-Wiener and Pielou indices (Magurran, 1996) were used to describe the monthly diversity $\left(H^{\prime}\right)$ and homogeneity $(J)$ of the copepod population. Figure 4 shows that whereas the diversity generally increased during the rainy season in November and May, homogeneity was relatively constant. The bloom of Pseudodiaptomus sp. in April significantly depressed both indices. Copepod diversity in subtropical and temperate coastal inlets and bays is documented to vary from 18 to 43 species and 14 to 26 genera (Nair et al., 1981; Kimmerer \& Mickinnon, 1985; Michel \& Herring, 1984; Webber \& Roff, 1995). Unfortunately, data and information regarding copepod diversity for tropical creeks, especially along the East African coast, is very scarce.

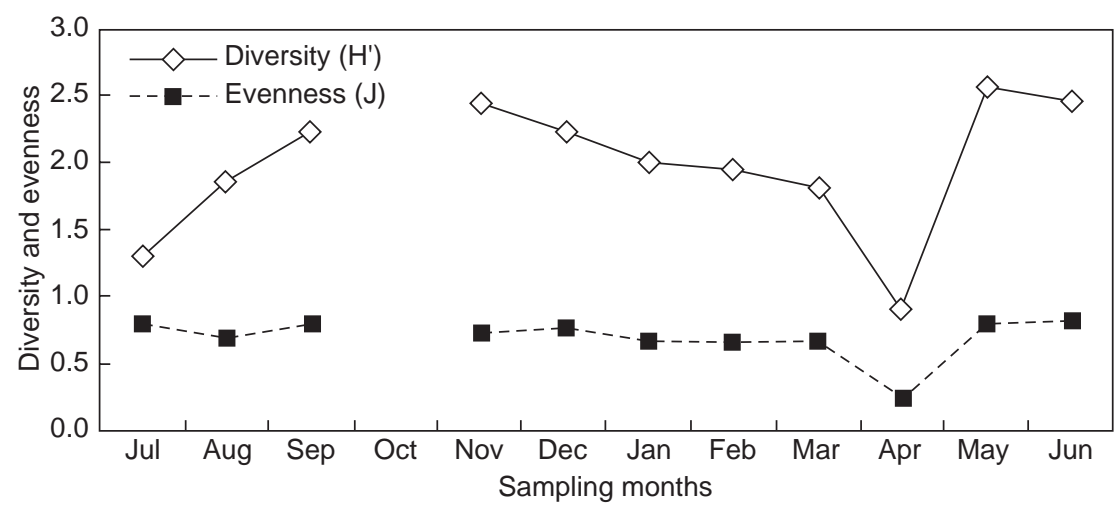

Fig. 4. Monthly variation of diversity and evenness of copepods in Makupa creek and Mombasa Harbour 


\section{CONCLUSION}

Unlike other creeks of the Kenya coast, Makupa creek is effectively shielded from the open ocean due to its location and geomorphology. It is therefore considerably influenced by land runoff especially during the wet season. Due to the narrow and shallow nature of Kipevu Channel, which connects the creek to the Indian Ocean via Mombasa Harbour, flushing is poor. Thus the creek water, except during periods of extreme tides, may be expected to have extended resident time when compared to water in the neighbouring creeks, lagoons and bays.

Recent hydrodynamic studies of the creek ( $\mathrm{J}$. Kitheka, pers. commun.; unpublished data) reveal that it is usually completely flushed during spring tides, thus it has high rates of water exchange despite its enclosed nature. None of the physical parameters measured (mainly temperature and salinity) showed any stable condition - they varied with tidal and seasonal cycles.

The temperature and salinity ranges were very narrow all the year round, which is typical of tropical creeks. Therefore, high levels of BOD and other chemical conditions (Mwangi et al., unpublished data) were presumably the main contributing factors that caused biological and chemical instability. As a result, the factors may be responsible for the current unfavourable conditions of Makupa creek for the survival of copepods, other invertebrates and even fish.

Copepod abundance peaked during the NEM period and was usually highest at Stn 5 (up to 209/ $\mathrm{m}^{3}$ ) and Stn 3 (up to $78 / \mathrm{m}^{3}$ ), which are the stations located close to the open ocean. At least 51 copepods species belonging to 38 genera were identified in Makupa creek and Mombasa Harbour. They were dominated by five major genera namely Acartia, Acrocalanus, Corycaeus, Oithona and Oncaea. These may be referred to as the characteristic copepod community of this locality. The five genera very often occurred together (cooccurred) each month at Stns 5 and 3. On the contrary, only two or at most three genera of these major copepods dominated in the other three Stns (1, 2 and 4). Station 5 was located in Mombasa Harbour close to the open ocean while Stn 3 was adjacent to it, though it was inside the creek.
Results indicate that copepod species richness in Makupa creek is much less than in the adjacent waters which include Mombasa Harbour, the neighbouring creeks, bays and the neritic waters of East African coast in general. This is probably because this creek, due to its geomorphology and location, tends to accumulate contaminants derived from dumped raw municipal wastes. Mombasa residents produce an estimated 650 tonnes of industrial and domestic wastes daily (Osore, unpublished data) half of which has always been dumped at the shores of Makupa creek over the years. Additionally, routine operational activities of the Mombasa Harbour including storage (and subsequent accidental seepage) of crude oil, ship maintenance works etc., may be some of the factors contributing to environmental degradation.

Based on this and similar other research (including Abuodha \& Kairo, 2001; Kamau, 2001; including various unpublished data) compared with results from adjacent locations, the authorities of the City of Mombasa have decided to relocate the dumping site from the shores of Makupa creek to a new site at Mwakirunge located to the northeast of Mombasa and further away from the coastline. Hopefully, due to the relocation of the dumping site, the fauna and flora of this degraded area will soon be restored.

This study presents a preliminary list of copepods that are associated with the kind of environmental degradation that Makupa creek has been experiencing. However, in order to effectively capture the entire representative copepod population of this creek, we recommend that sampling of zooplankton in future should employ not only the $335 \mu \mathrm{m}$ but also the $180 \mu \mathrm{m}$ mesh size nets. The copepod list is undoubtedly a useful contribution to the knowledge of the extant fauna in Makupa creek especially during the process of ecological recovery of this creek.

Acknowledgements-We are grateful to KWS through Dr N. Muthiga for providing logistical assistance for field sampling and to KMFRI for availing laboratory space and equipment during this research project. We acknowledge efforts by Mr Steve Mwangi, the team leader in the field, and we thank the following KMFRI technologists: Ms Ombegi and Messrs Kamau, Kilonzo, Kimanthi, 
Onduso and Omambia. We are indebted to Prof. S. Uye of Hiroshima University and also to Prof. José Paula of University of Lisbon whose critical comments and suggestions immensely improved the quality of the manuscript.

\section{REFERENCES}

Abuodha, P.K. \& Kairo, J.G. (2001) Human induced stresses on mangrove swamps along the Kenya coast. Hydrobiologia 458: 255-265.

Borger, R. (1990) Inleidende studie vaan de zooplanktongemeenschap van een mangrove kreek, Gazi, Kenya. Licentiaatsthesis in de Dierkundige Wetenschappen, Vrije Universiteit Brussel. 75 pp.

Bradford, J.M. (1972) Systematics and ecology of New Zealand central east coast plankton sampled at Kaikoura. Bull. N. Z. Dept. Sci. \& Ind. Res. 207: $1-89$.

Giesbrecht, W. (1892) Systematik und Faunistik der Pelagischen Copepoden des Golfes von Neapel und der angrenzenden Meeres-Abschnitte. Fauna und Flora des Golfes von Neapel. 19: 1-831.

Kamau, J.N. (2001) Heavy metal distribution in sediments along the Kilindini and Makupa creeks. Hydrobiologia 458: 235-240.

Kimaro, M.M. \& Jaccarini, V. (1989) The cycle of near surface zooplankton abundance in Tudor Creek, Mombasa, Kenya. Kenya J. Sci. Techn. Ser. B. 10: 7-30.

Kimmerer, W.J. \& Mackinnon, A.D. (1985) A comparative study of the zooplankton in two adjacent embayments, Port Phillip and Westernport Bays, Australia. Est., Coast. Shelf Sci. 21: $145-159$.

Kitheka, J.M., Ohowa, B.W., Mwashote, B.M., Shimbira, W.S., Mwaluma, J.M. \& Kazungu, JM. (1997) Water circulation dynamics, water column nutrients and plankton productivity in a well-flushed tropical bay in Kenya. J. Sea Res. 35: 257-268.

Magurran, A.E. (1996) Ecological diversity and its measurements. Chapman \& Hall, London. 192 pp.

Mauchline, J. (1998) The biology of calanoid copepods. Adv. Mar. Biol. 33: 1-710.

Michel, H.B. \& Herring, D.C. (1984) Diversity and abundance of Copepoda in the northwestern Arabian Gulf. Crustaceana, Suppl. 7: 326-335.

Munga, D., Yobe, A.C., Owili, M. \& Mwaguni, S.M. (1994) Assessment of land-based sources of marine pollution along the Kenya coast. Report presented to the World Health Organisation, Regional Office, Brazzaville. $60 \mathrm{pp}$.

Mwaluma, J.M. (2000) Distribution, abundance and composition of zooplankton along three transects off the Kenya coast. MSc Thesis, University of Nairobi. 72 pp.

Nair, S.R.S., Nair, V.R., Achuthankutty, C.T. \& Madhupratap, M. (1981)Zooplankton composition and diversity in western Bay of Bengal. J. Plank. Res. 3: 493-508.

Okemwa, E.N. (1989) Analysis of six 24 hours series of zooplankton sampling across a tropical creek, the Port Reitz, Mombasa, Kenya. Tropical Zoology 2: 123-138.

Okemwa, E.N. (1990) A study of the pelagic copepods in a tropical marine creek Tudor, Mombasa, Kenya with special reference to their community structure, biomass and productivity. PhD Thesis, Vrije Universiteit Brussel. 225 pp.

Okemwa, E.N. (1992) A long-term sampling study of copepods across a tropical creek in Mombasa, Kenya. E. Afr. Agric. For. J. 57: 199-215.

Okemwa, E.N. \& Revis, N. (1986) Planktonic copepods from coastal and inshore waters of Tudor Creek, Mombasa. Kenya J. Sci. Techn. Ser. B. 7: 27-34.

Okemwa, E.N. \& Revis, N. (1988) Additional records of species of copepods and their distribution in the coastal and inshore waters of Kenya. Kenya $J$. Sci. Ser. B 9: 123-127.

Okera, W. (1974) The zooplankton of inshore waters of Dar-es-Salaam, Tanzania (S.E. Africa) with observation on reaction to artificial light. Mar. Biol. 26:13-25.

Osore, M.K. (1992) A note on the zooplankton distribution and diversity in a tropical mangrove creek system. Gazi, Kenya. In: Jaccarini, V. \& Martens, E. (eds). The ecology of mangroves and related ecosystems. Kluwer Academic Publishers, Dordrecht, the Netherlands. pp. 119-120.

Osore, M.K.W. (1994) A study of the zooplankton of Gazi Bay, Kenya and the adjacent waters: community structure and seasonal variation. MSc Thesis, Vrije Universiteit Brussel. 104 pp.

Osore, M.K., Mwaluma, J.M. \& Okemwa, E.N. (1993) Zooplankton studies in the mangrove ecosystem of Gazi, Kenya. In: A. Woitchick (ed.) Dynamics and assessment of Kenyan mangrove ecosystems. EEC Project no. TS-0240-C (GDF). Brussels. pp. $12-14$.

Osore, M.K., Tackx, M.L. \& Daro, M.H. (1997) Effect of rainfall \& tidal rhythm on the community structure \& abundance of the zooplankton of Gazi Bay, Kenya. Hydrobiologia 356: 117-126.

Osore, M.K., Zhu, L., Tackx, M.L. \& Daro, M.H. (1995) Zooplankton communities of Kenya during the northeast monsoon period. In: Heip, C.R.H. \& Hemminga, M.A. (eds) Monsoon and coastal ecosystems of Kenya. Nat. Mus. Nat. Hist., Leiden, The Netherlands. pp. 108-112. 
Owre, H.B. \& Foyo, M. (1967) Copepods of Florida current fauna. Caribbea 1: 1-37.

Parsons, T. R., Maita, Y. \& Lalli, C.M. (1984) A manual of chemical and biological methods for seawater analysis. Pergamon Press. 173 pp.

Reay, P.J. \& Kimaro, M.M. (1984) Surface zooplankton studies in Port Mombasa during the northeast Monsoon. Kenya J. Sci. Techn. Ser. B 5: 27-48.

Revis, N. (1988) Preliminary observations on copepods of Tudor Creek, Mombasa, Kenya. Hydrobiologia 167/168: 343-350.

Rose, M. (1933) Copepodes pelagiques. Faune de France 26. Lechevalier, Paris. 374 pp.

Smith, S.L. \& Lane, P.V.Z. (1981) Biological Oceanography of the Somali Current Data Report. Informal Data Report no. 29098 Brookhaven National Laboratory, Upon New York. 126 pp.
Walter, T.C. (1989) Review of the new world species of Pseudodiaptomus (Copepod: Calanoida), with a key to the species. Bull Mar. Sci. 45: 590-628.

Webber, M.K. \& Roff, J.C. (1995) Annual structure of the copepod community and its associated pelagic environment off Discovery Bay, Jamaica. Mar. Biol. 123: 467-479.

Wickstead, J.H. (1965) An introduction to the study of tropical plankton. Hutchinson and Co., London. $160 \mathrm{pp}$.

Williams, T.M., Rees, J.G., Kairu, K.K. \& Yobe, A.C. (1996) Contaminant, transport and storage in the estuarine creek systems of Mombasa, Kenya. British Geological Survey Overseas. Geology Series Technical Report WC/96/42. 85 pp. 